\title{
Mass Concentration of Airborne Particulates in Selected Museums at Kuala Lumpur and Perak
}

\author{
Norsyamimi Hanapi, Shamzani Affendy Mohd Din \\ Kulliyyah of Architecture \& Environmental Design, \\ International Islamic University Malaysia, \\ P.O.Box 10, 50728 Kuala Lumpur, Malaysia. \\ *syamimi_hnfi88@ymail.com
}

\begin{abstract}
Indoor pollutants gives harmful effects to human health and became the main cause of the cultural heritage deterioration. The research is focuses on the airborne particulates at the indoor of the museum galleries. Equipment used to sample inhalable dust was the 7-hole sampler and the Cyclone sampler for sample respirable dust. The results show that mass concentrations at selected location were exceeding the limit of safety Indoor Air Quality (IAQ) and Malaysia standard limit for TSP and PM10 in 8 hours sampling. Thus, it is important to control the level of contaminants within the buildings for safety purposes.
\end{abstract}

Keywords: Air Pollution ; Airborne Particulates ; Indoor ; Human Health ; Cultural Heritage.

eISSN 2514-751X @ 2018. The Authors. Published for AMER ABRA cE-Bs by e-International Publishing House, Ltd., UK. This is an open-access article under the CC BY-NC-ND license (http://creativecommons.org/licenses/bync-nd/4.0/). Peer-review under responsibility of AMER (Association of Malaysian Environment-Behaviour Researchers), ABRA (Association of Behavioural Researchers on Asians) and CE-Bs (Centre for EnvironmentBehaviour Studies), Faculty of Architecture, Planning \& Surveying, Universiti Teknologi MARA, Malaysia.

DOI: https://doi.org/10.21834/aje-bs.v4i15.25 


\subsection{Introduction}

The problem of Indoor Air Quality (IAQ) has given crucial impact to human health and has been discussed by the world for about half century. Pollutants in the air are caused by natural events and human activities. This research focuses on the human activities that contributesactivities that contribute to air pollution such as industrial activity, construction works and driving vehicles. The scope of area for this research is airborne particulates, human health and cultural heritages. The relationship of these erratic matters will be discussed by studying on the effects of airborne particulates towards heritage items at the selected study sites in Manjung District, which is near to the industrial activity; Manjung CoalFired Power Plant and Lumut Power Plant, Perak Darul Ridzuan and also at National Museum, Kuala Lumpur, Malaysia. It is to be highlighted here that this research aims is to focus on the mass concentration of airborne particulates matter indoor of heritage building at Manjung District, Perak Darul Ridzuan and National Museum, Kuala Lumpur. The objectives of the research acknowledged the followingsas follows :-

- To identify the sources of airborne particulates in selected museums

-To measure and quantify particulate matters and IAQ in thein the selected museum galleries -To classify the effects of particulates matter, humidity and temperature towards human health and artefacts

-To propose the methods of displaying artefacts and reducing particulates matter in museum

\subsection{Literature Review}

\subsection{Atmospheric pollution}

Atmospheric pollution is the presence of one or more contaminants in the air in such a concentration and of such duration as to cause a nuisance or to be injurious to human life, animal life or vegetation. The pollutants of the air may come from various sources such as industrial activity like factory emissions, waste products, transportation and construction works (SAM, 2010). The large number of health-damaging air pollutants include Carbon Monoxide (CO), Nitrogen Dioxide (NO2), Ozone (O3), Sulphur Dioxide (SO2), and Particulates matter specifically coarse, fine and inhalable PM10 and PM2.5 (Nik Nurul Hidayah and Shamzani Affendy, 2011). Air pollution is caused by gases and particles, both liquid and solid, which contaminate the environment. Sjaak Slanina (2008) has stated that most of pollutants are emitted both by natural and anthropogenic sources. Those activities will generate airborne particulates and hazardous gases that can pollute the air that we inhale. Atmospheric pollution causes harm to the comfort, health or welfare of people or the environment. (Zactruba, 2009).

\subsection{Airborne particulates matter}

Particulate Matter (PM) is a complex mixture of extremely small solids and liquid droplets. It is made up of a number of components, including acids (such as nitrates and sulfates), organic chemicals, metals, and soil or dust particles as stated by the CAl-Asia Center (2010). Airborne particulate matter represents a complex mixture of organic and inorganic 
substances. Mass and composition in urban environments tend to be divided into two principal groups: coarse particles and fine particles. The barrier between these two fractions of particles usually lies between $1 \mu \mathrm{m}$ and $2.5 \mu \mathrm{m}$. (Green Facts Scientific Board, 2010). The standard of Total Suspended Particulate (TSP) for 24 hours in Malaysia by Department of Environment, DOE (2006) is $260 \mu \mathrm{g} / \mathrm{m} 3$ or $0.260 \mathrm{mg} / \mathrm{m} 3$. Thus, the standard TSP in 8 hours is about $0.08 \mathrm{mg} / \mathrm{m} 3$. Furthermore, standard guideline for PM10 in Malaysia is $0.05 \mathrm{mg} / \mathrm{m} 3$ in 8 hours sampling. This standard level of airborne particulates in Malaysia will be used as a guideline in analyzing data gained after dust sampling process conducted by the researcher at selected site studies.

\section{0 Methodology}

\subsection{Case study}

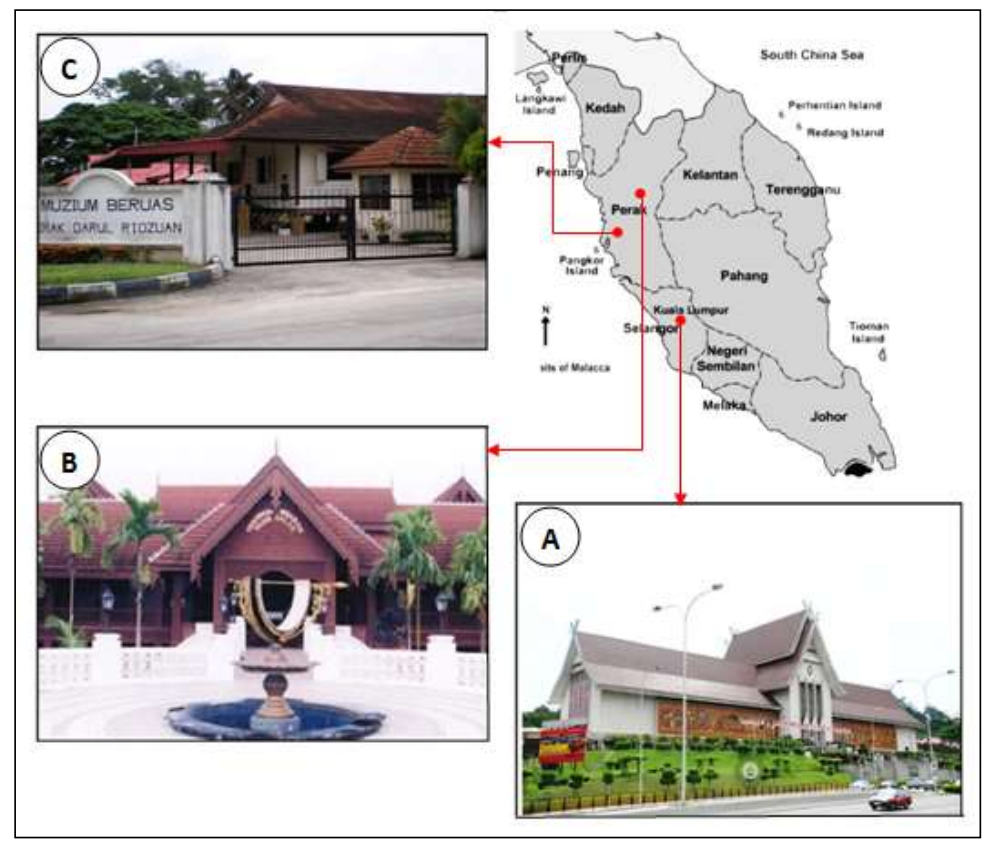

Figure 1: Selected museums in Peninsular Malasyia as the location for airborne particulates sampling ; National Museum (A), Pasir Salak Historical Complex (B), and Beruas Museum (C).

A) National Museum is located in Kuala Lumpur and surrounded by several building constructions. Construction activities did give big impact to the air pollution issues in Malaysia. From the three case studies, mass concentrations of airborne particulates were calculated and compared in order to determine which building has the highest level of 
pollutants.

B) The Pasir Salak Historical Complex is situated at $70 \mathrm{~km}$ from the Ipoh city. This historical complex was chosen as one of the case studies because of its location that is besides the river. The particulates blown by the river wind may affect the air quality indoor of the complex. Besides, it is also to investigate whether the particulates from the combustion of coals at Manjung Coal-Fired Power Plant station reach that site.

C) Beruas Archaeological Museum is a small museum in the town of Beruas, in Manjung District, Perak.. The traffic flows at site were quite busy everyday. The capability of the airborne particulates that come from transportations is high. Air sampling was done inside the exhibition gallery.

\subsection{Environmental air sampling}

The scientific data collections are expanded further by measuring airborne particulates. The tool and equipments used include Mass Balance, 7-Hole sampler, Cyclone sampler, Calibrators, and other supported tools. Sampling devices wereare used to collect the airborne particulate from a measured volume of air whichair, which wereare measured as mass concentration and reported as milligram of particulate per cubic meter of air $(\mathrm{mg} / \mathrm{m} 3)$. Inhalable 8-hours air sampling are using Casella 7-hole sampler at 2.0 L/min air flow (Fig.2a) and cyclone sampler at $2.2 \mathrm{~L} / \mathrm{min}$ air flow for respirable 8-hours air sampling (Fig.2b).

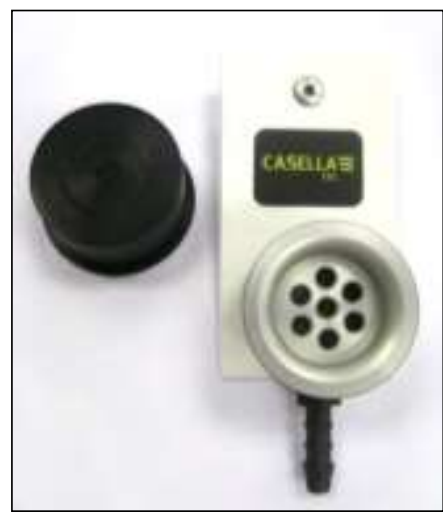

(a)

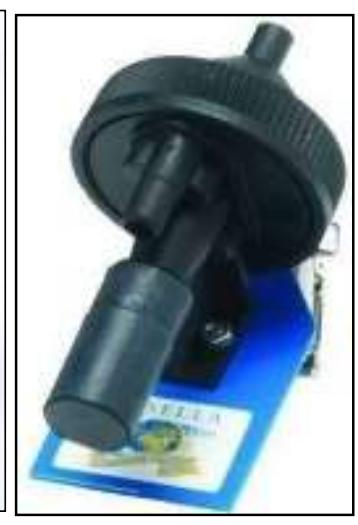

(b)

Figure 2: (a) 7-hole sampler ; (b) Cyclone sampler

\subsection{Data collection}

The researcher usede both primary and secondary data for this study. Besides gaining data from literature review, researcher had quantified the particulates with the chosen method in order to get more constructive data. Data was collected inside the exhibition galleries of selected museums. The information of the data collected are is as stated in Table 1. 
The mass concentration of the airborne particulates suspended in the air was calculated basede on the environmental condition of the study site study and the possible sources of the particulates at those locations. In addition to relate the research with cultural heritage, Testo 461 (Fig.3) was used to read temperature and relative humidity indoor of the selected case study. It is to prove that climatic change also givese bad impact towards artefacts.

Table 1: The information of data gained at selected museum in Peninsular Malaysia Location

\begin{tabular}{llllll}
\hline & \multicolumn{4}{l}{ Data collection } & \multicolumn{2}{l}{ Time /period } \\
\cline { 2 - 6 } & Day & Date & a.m & p.m & duration \\
\hline National Museum & Weekday & $15 / 03 / 2011$ & 9.00 & 5.00 & 8 hour \\
Beruas Museum & weekday & $21 / 03 / 2011$ & 8.30 & 4.30 & 8 hour \\
Pasir Salak Historical Complex & weekday & $22 / 03 / 2011$ & 9.45 & 5.45 & 8 hour \\
\hline
\end{tabular}

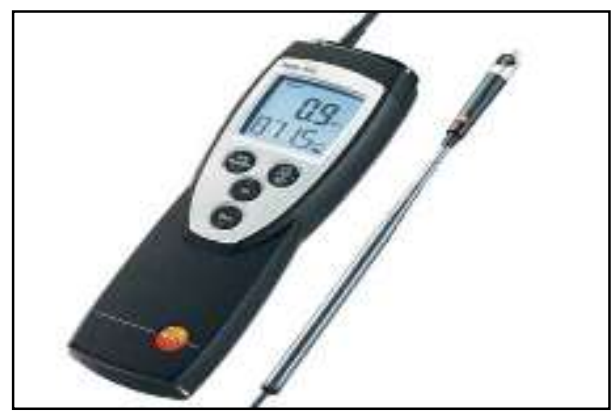

Figure 3 : Testo 461

\subsection{Results and Discussion}

The issue of Indoor Air Quality (IAQ) in Malaysia buildings has been discussed by many researchers. The mass concentration of airborne particulate at selected museums isare exceeding the standard level of Total Suspended Particulates (TSP) in Malaysia (EPD, 1987) and over the limit of good IAQ (CAI-Asia Center, 2010).

\subsection{Particulates matter in galleries}

According to the National Standard level of Total Suspended Particulates (TSP) in Malaysia as stated by CIA-Asia Center (2010), the standard level of TSP in Malaysia is $0.260 \mathrm{mg} / \mathrm{m} 3$ which means $0.260 \mathrm{mg} / \mathrm{m} 3$ in 24 hours. Based on this, it can be highlighted that the standard level of TSP for Malaysia in 8 Hours period is $0.08 \mathrm{mg} / \mathrm{m} 3$ while PM10 is $0.05 \mathrm{mg} / \mathrm{m} 3$. The researcher agreeds that the mass concentration gathered from 7-Hole sampler should be higher than the Cyclone sampler as stated by Shamzani (2007). 


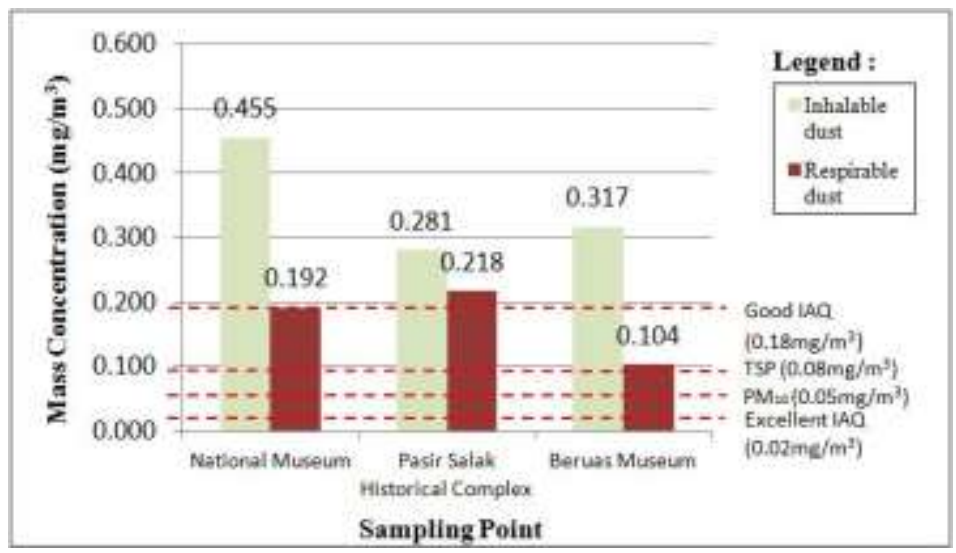

Figure 4 :Comparison of Airborne Particulates mass concentration in selected museums with the level of PM10 (DOE,2006), Good and Excellent IAQ by EPD (1987) in 8 Hours

From the findings gathered, the level of respirable and inhalable dust at National Museum and Pasir Salak Historical Complex wasare higher than the standard level based on the Hong Kong Air Quality Objectives by EPD (1987), that a good IAQ of indoor for respirable dust is $0.018 \mathrm{mg} / \mathrm{m} 3$ in average 8 hours and $0.02 \mathrm{mg} / \mathrm{m} 3$ for excellent IAQ. As the mass concentration for respirable particulate wasis over the standard level of Good IAQ and the standard level of Total Suspended Particulates (TSP) and PM10 for Malaysia, the situation may create high riskhigh-risk airborne particulates exposure within the building towards occupants whichoccupants, which needs to be controlled. The particulates that wereare trapped in the museums may become a risk and create health problems to the visitors as well.

\subsection{Temperature and relative humidity collection}

Table 2 is the summary of relative humidity and temperature measured at the selected museums. Relative humidity and temperature at those locations were noted down by the researcher in the morning and evening to make comparison and notify the change of the readings.

From the findings, the relative humidity at the selected locations changeds in a range of $6 \%$ to $11 \%$ in 8 hours. It means that the level of indoor moisture indoor wasis not stable and not well maintained, thus may give effects to affect the organic materials like wood, paper or textiles. In terms of temperature, the findings show that National Museum faced the highest change whichchange, which wasis $2.2 \mathrm{OC}$ earlier but changed to, followed by $0.9 \mathrm{oC}$ changes at Pasir Salak Historical Complex, and $0.8 \mathrm{oC}$ at Beruas Museum. The combination of high changes in temperature and humidity with airborne particulates may generate many harmful effects towards building materials or artefacts such as mould growth, corrosion of metal, brittleness of paper and so on 
Table 1: The information of data gained at selected museum in Peninsular Malaysia

\begin{tabular}{llllllll}
\hline Location & \multicolumn{3}{c}{ Relative Humidity $(\%)$} & \multicolumn{3}{c}{ Temperature $\left({ }^{\circ} \mathrm{C}\right)$} \\
\cline { 2 - 7 } & a.m & p.m & change & a.m & p.m & change \\
\hline National Museum & 65.1 & 54.4 & 10.7 & 26.5 & 28.7 & 2.2 \\
Beruas Museum & 56.9 & 50.0 & 6.9 & 23.7 & 24.5 & 0.8 \\
Pasir Salak Historical Complex & 58.7 & 57.8 & 0.9 & 25.9 & 24.0 & 0.9 \\
\hline
\end{tabular}

\subsection{Effects of airborne particulates towards human health}

Health means being in a state of complete physical, mental, and social well-beingwell-being and not merely the absence of disease or infirmity (WHO, 2010). Thus, it can be explained that the impact of air pollution on human health is the direct effect from the particulates matter towards the well-being of human health. TSP and black smoke were used as indicators of airborne particles in the past but TSP has lost relevance because these can be filtered by nose and mouth. PM10 and PM2.5 are moreis preferred for more targeted response to the problems related with PM exposureexposure, as they are more dangerous to public health. Airborne particulates may become harmful to human health that can cause Lung disease, Asthma, Strokes, respiratory tract disorders, numerous forms of cancer, eyes or skin irritations and allergic (Senthamizhvanan, 2010).

As stated by Gaynor Barade (2010), lack of proper ventilation causes the radon emission from the earth to be trapped indoors, within houses and offices. The use of air fresheners, pesticides and chemical sprays also put the people in the immediate environment at risk of developing respiratory tract disorders, poisoning and fatalities. Toxicfatalities. Toxic asbestos fibers, dust and fumes cause Mesothelioma, a cancer that eats into the mesothelium, a delicate tissue that engulfs and protects important organs such as the heart and the lungs. While pets shed dander into the atmosphere, humans produce dust from dead skin flakes and the decomposition of hair. Lookwood et. al., (2009) and Norsyamimi Hanapi (2011) have studied the effects of airborne particulates generated by coal power plant towards human health in United States (US) and Malaysia. As reported, Coal pollutants affect all major body organ systems and contribute to four of the five leading causes of mortality in the countries (heart disease, cancer, stroke, and chronic lower respiratory diseases).

\subsection{Airborne particulates impact on cultural heritage}

Air pollution has various effects on historical heritage materials such as the corrosion of metals, the deterioration of materials and paints, also the fading of dyes. This research figureThis research figures out deterioration of artefacts at Beruas Museum. The deterioration of materials caused by various possible factors such as humidity, temperature, particulates, light exposure, mould, insect attack, microorganisms, chemical reaction, mishandling and improper display methods. Fig. 5 shows the impact of airborne particulates and other agents of decay towards artefacts at Beruas Museum. 


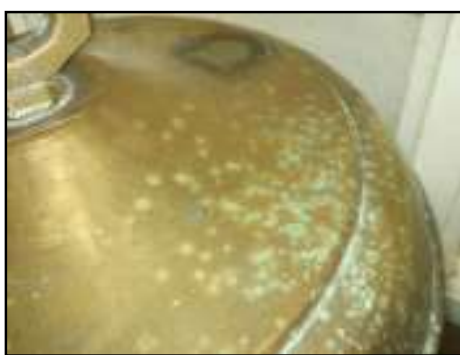

(a)

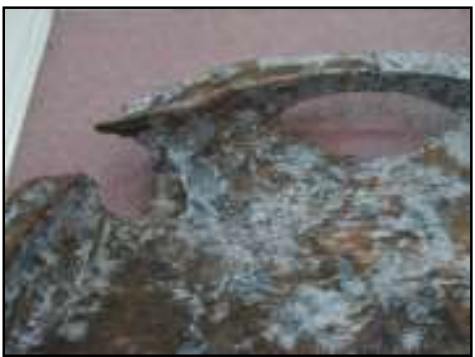

(b)

Figure 5 : (a) Bronze disease (b) White rots

Literature reports many degradation cases of heritage objects' constituent materials such as paper, leather, textiles, pigments, and metal by the air pollutions (Puica and Ardelean, 2008). The effects of indoor air pollutions towards materials are different and variety due to the type of pollutants in the air. R Ahmad (2010) stated that the negative impact can occur when the pollutants react with the other environmental factors such as moisture, air, salt, particulate matter, ozone, light, physical wear, washing, sunlight, temperature, microorganism and etc

\subsection{Conclusion}

Based on the research findings, this study or knowledge seems to be new in Malaysia and it was getting more serious. From this research, it is found that all sampling location had exceeded the limit of Malaysia standard PM10 and TSP standard by DOE (2006). This means that indoor air quality of selected museum waswere not safe to the occupant and visitors as it may bring negative impact towards them. Indoor air pollution is the best scope of research to be conducted as the particulates generated by industrial activities such as coal power plants stations, transportations and construction works have become a crutialcrucial issue. As the air is the most important elements in living, the level of particulates suspended in the air that exceeds the limit of standard TSP in Malaysia will give harmful effects towards human health and materials. This research is beneficial for museum occupants and visitors especially those which who are exposed to the sources of particulates such as coal power plant station, construction works, and vehicles.

In terms of airborne particulate matter (PM), the emissions can be minimized by pollution prevention and emission control measuresMeasuresmeasures. Measures such as improved process design, operation, maintenance, housekeeping, and other management practices can reduce emissions. There are some opinions or suggestions to reduce the particulates emission inside building in order to decrease the bad impacts of airborne particulates towards human health and artefacts:-

- $\quad$ Reducing ventilation rates in which outdoor air enters the building

- Improving particles filtration and control the use of HVAC System 
- $\quad$ Using display cases and framing methods for displaying artefacts

- $\quad$ Limiting sources of indoor pollutants ; cleaning and vacuumingl

- $\quad$ Provide open space and organic plants as an alternative method

More studies need to be carried out to understand the dangerous effects of Airborneairborne particulates towards human health, nature and materials. The Ministry of Health $(\mathrm{MOH})$ or government of Malaysia through DOE needs to increase the level of information on air pollution. Thus, should provide or manage the number of campaign, talk, seminar and workshop about the risky level of air pollution in Malaysia that can give answers to all problem issues that have been discussed in this paper. The in-depth study of the airborne particulates effect towards human health and materials in Malaysia, as well as the relationship between both subjects should also be studied further and investigated. Future research studies should also look into physical characterizations and size distributions of airborne particulates generated by different sources of nature events and human activities in Malaysia.

\section{Acknowledgement}

I would like to thank Asst. Prof. Dr. Shamzani Affendy Bin Mohd Din, from the Kulliyyah of Architecture \& Environmental Design (KAED), International Islamic University Malaysia (IIUM) for his supervision, and advice on airborne particulates sampling. Support by group research was also gratefully acknowledged

\section{References}

Allan Lookwood, Kristen Kelker Hood, Molly Rauch, and Barbara Gottlieb. (2009). Coal's Assault on Human Health, a Report from Physicians for Social Responsibility. Retrieved from www.psr.org/coalreport.

CAI-Asia Center. (2010). Particulate Matter (PM) Standards in Asia. Retrieved from www.cleanairinitiative.com.

DOE. (2006). Malaysia Environmental Quality Report. Department of Environment, Ministry of Natural Resources and Environmental Malaysia.

EPD. (1987). Hong Kong Air Quality Objectives Under the Air Pollution Control Ordinance. Retrieved from www.iaq.gov.

Gaynor Barade. (2010). Effects of Air pollution. Retrieved from www.buzzle.com.

Green Facts Scientific Board. (2010). Fine Particles. Retrieved from www.greenfacts.org.

Nicoleta Melcinius Pulca \& Elene Andelean. (2008). The Industrial Pollution Impact on Religious Heritage in Romania. European Journal of Science and Theology.

NikNurul-Hidayah and ShamzaniAffendy, (2011). A Study of Air Pollution Caused By the Construction Industry and Its Effect towards Workers and Project Implementation. International Research Invention and Innovation Exhibition .Malaysia. 
Norsyamimi Hanapi. (2011). The Effects of Ariborne Particulates towards Historical Heritage at Manjung, Perak Darul Ridzuan and National Museum, Kuala Lumpur. (Degree Design Thesis, International Islamic University Malaysia).

R.Ahmad (2010). Air Pollution Damage to Material in the Indoor Environment. Retrieved on January 172011 from www.infim.ro/cost/pagini/workshop.

University Malaysia).

Sahabat Alam Malaysia. (2010). A to Z of the Malaysia Environment. Retrieved from www. surfoever. com/sam.

Senthamizhvanan.(2010). Air pollution. Retrieved from www.senthamizhvanan.blogspot.com/ 2010/11/ airpollution.html.

Sajak Slanina (2008). Air Pollution Emissions. Anthropogenic and Natural Emission. Retrieved from www.eoearth.org.

Shamzani Affendy Mohd Din. (2007). Collection and Physical Characterisations of Airborne Particulates. (Doctor of Philosophy Thesis, Cardiff University of United Kingdom).

WHO, W. H. (2010). Health. Retrieved from World Health Organization: http://www.who.int/media centre/factsheets/fs313/en/index.html 